\title{
Regional Activity of Galactose-1-Phosphate Uridyltransferase in Rat Brain
}

\author{
SHIRLEY ROGERS, RANDALL HEIDENREICH, JOHN MALLEE, AND STANTON SEGAL
}

Division of Biochemical Development and Molecular Diseases, Children's Hospital of Philadelphia. Departments of Pediatrics and Medicine, University of Pennsylvania School of Medicine, Philadelphia, Pennsylvania 19104

\begin{abstract}
The sp act of galactose-1-phosphate uridyltransferase has been measured in individual regions of adult rat brain to see if site-specific differences in enzyme activity can aid in the understanding of brain abnormalities observed in well-treated galactosemic patients. The sp act in the cerebellum, brain stem, and midbrain were higher than in the cortex, hippocampus, and striatum. Activity in the cerebellum was 2 -fold greater than that found in the cortex. Steady state levels of mRNA of the enzyme in the cerebellum were twice that of the cortex corresponding to the ratio of enzyme sp act in the two regions. Measurement of the kinetic parameters in tissue from the cerebellum and cortex revealed that the regional specificity in enzyme activity observed in the brain represents differences in the $V_{\max }$. Inhibition of the enzyme by uridine and uridine triphosphate was essentially the same for all regions and was not influenced by the 2 -fold differences observed in the levels of enzyme. Inhibition by uridine was significantly greater than that for uridine triphosphate. (Pediatr Res 31: 512-515, 1992)
\end{abstract}

Abbreviations
UDPglucose, uridine diphosphate glucose
UDPgalactose, uridine diphosphate galactose
UTP, uridine triphosphate
SSC, sodium chloride, sodium citrate

Abnormal brain function has been a hallmark of the clinical syndrome associated with galactose-1-phosphate uridyltransferase deficiency galactosemia (1). Diminished intelligence and learning disorders $(2,3)$ and speech defects $(4,5)$ have been characteristics of the disorder even with early recognition and initiation of a galactose-restricted diet (3). In the stage of acute galactose toxicity, pseudo-tumor cerebri has been reported (6). Despite dietary therapy, many older galactosemic patients exhibit abnormal EEG patterns (2). Recently, there have been a number of reports (7-10) of the development of ataxic neurologic abnormalities in older children and adults indicative of cerebellar dysfunction. Indeed, Bohles et al. (9) described atrophy of the cerebellum, brain stem, and basal ganglia by computerized tomography.

There have only been rare descriptions of the neuropathologic findings of the brain of patients with galactosemia. Both Crome (11) and Haberland et al. (12) reported alteration in basal ganglia, brain stem, and cerebellum where there was marked loss of Purkinje cells in a 5-y-old and a 15 -y-old patient. Suzuki et al.

Received October 23, 1991; accepted January 9, 1992.

Correspondence and reprint requests: Stanton Segal, M.D., Children's Hospital of Philadelphia, Division of Biochemical Development and Molecular Diseases, 34th Street \& Civic Center Boulevard, Philadelphia, PA 19104

Supported by National Institutes of Health Grant DK 42785
(13) described degenerative changes of cerebellar Purkinje cells in a 4-mo-old infant succumbing to the disease.

These findings suggested that the regional brain alterations in galactosemia may be related to the site-specific loss of galactose1-phosphate uridyltransferase activity. We have, therefore, examined the sp act of this enzyme in several regions of the rat brain to determine if differences in activity of the enzyme correspond to regions of the brain clinically affected in the human disorder. We have found that the sp act of the enzyme is high in brain stem, midbrain, and cerebellum, which has nearly twice the level of cortex. Also, the steady state mRNA level of the enzyme closely parallels the enzymatic activity of the latter two regions.

\section{MATERIALS AND METHODS}

Sprague-Dawley rats, from Charles River Breeding Farms (Wilmington, MA), were housed three per cage in a room with a light/dark cycle of 10:14 h where all animals had free access to food and water. Tissue from exsanguinated animals was dissected on an ice-cold surface. Individual regions of the brain were quickly frozen between blocks of dry ice and stored at $-76^{\circ} \mathrm{C}$ for enzyme analysis and RNA isolation. White matter was separated from the cortex and the gray matter-enriched fraction retained for analysis. Biochemicals were purchased from Sigma Chemical Co. (St. Louis, MO), radiolabeled $\left[{ }^{14} \mathrm{C}\right] \mathrm{D}$-galactose-1-phosphate was obtained from New England Nuclear (Boston, MA), and uridine diphosphate $\left[{ }^{14} \mathrm{C}\right]$ glucose from Amersham (Arlington Heights, IL). The ion exchange paper, diethylaminoethyl cellulose, was a product of Whatman Inc. (Clifton, $\mathrm{NJ}$ ).

The measurement of the sp act of galactose-1-phosphate uridyltransferase was based on the radioisotope method of Bertoli and Segal (14), which has been used in a series of reports from this laboratory (15-17). Cell-free homogenates were prepared by homogenizing tissue with $8 \mathrm{vol}$ of $0.1 \mathrm{M} \mathrm{KCl}$ and the particulate matter removed by centrifugation at $30000 \times g$. Fifty $\mu \mathrm{L}$ of the soluble fraction were incubated with $0.25 \mathrm{mmol} / \mathrm{L}$ UDPglucose and $0.35 \mathrm{mmol} / \mathrm{L}$ galactose- 1 -phosphate, and the linear reaction terminated at $10 \mathrm{~min}$ by immersing the tubes in boiling water. Radiolabeled substrates and the corresponding products were separated by chromatography, and their respective areas counted in liquid scintillation fluid. Protein concentrations were determined using the Coomassie blue reagent and protein standard supplied by Bio-Rad (Richmond, CA). Enzyme sp act are expressed as nmol of product formed per min per $\mathrm{mg}$ soluble protein.

The apparent Michaelis-Menten constants were measured using Lineweaver-Burk plots (18) of initial velocities for a substrate concentration between 0.05 and $0.375 \mathrm{mmol} / \mathrm{L}$. Linear regression analysis of the data was used to compute the $\mathrm{V}_{\max }$ and $\mathrm{Km}$. To simplify calculations and eliminate isotope dilution as a factor, radiolabel was used for the substrate and kept at a fixed concentration, whereas the concentration of the nonradiolabeled substrate was varied. Thus, $\left[{ }^{14} \mathrm{C}\right]$ galactose-1-phosphate was fixed 
when UDPglucose was varied and uridine diphosphate $\left[{ }^{14} \mathrm{C}\right]$ glucose was fixed when galactose-1-phosphate was varied.

Total RNA were prepared by the method of Chomczynski and Sacchi (19). RNA was isolated by homogenizing $100 \mathrm{mg}$ of frozen tissue with $1 \mathrm{~mL}$ of $4 \mathrm{M}$ guanidinium thiocyanate, 25 $\mathrm{mM}$ sodium citrate ( $\mathrm{pH} \mathrm{7),0.5 \%} \mathrm{SDS,} \mathrm{and} 0.1 \mathrm{M}$ 2-mercaptoethanol. The following were added sequentially: $0.1 \mathrm{~mL}$ of $2 \mathrm{M}$ sodium acetate $(\mathrm{pH} \mathrm{4}), 1 \mathrm{~mL}$ of water-saturated phenol, and 0.2 $\mathrm{mL}$ of chloroform-isoamyl alcohol (49:1) with thorough mixing after each addition. The mixture was centrifuged at $10000 \times g$ for $20 \mathrm{~min}$, the supernatant removed, and the RNA precipitated at $-20^{\circ} \mathrm{C}$ for $1 \mathrm{~h}$ with $1 \mathrm{~mL}$ of isopropanol. The RNA was dissolved in $0.5 \%$ SDS and the concentration determined by absorption at $260 \mathrm{~nm}$ UV. Ten $\mu \mathrm{g}$ of total RNA were electrophoresed through a $1 \%$ agarose-formaldehyde gel (20) using 0.24 to 9.5-kb RNA size markers (BRL, Bethesda, MD) as standards. The RNA was transferred to a Zetabind membrane (CUNO) by capillary blotting using $10 \times$ SSC for $24 \mathrm{~h}$ and was UV-crosslinked to the membrane using a UV-Stratalinker 1800 (Stratagene).

A 786-bp rat transferase cDNA (unpublished data) was radiolabeled with $\alpha-{ }^{32} \mathrm{P}$-deoxycytidine triphosphate by random priming. Unicorporated counts were removed using Sephadex-G50 spun column chromatography. The rat $18 \mathrm{~S}$ ribosomal RNA 18mer oligonucleotide was end-labeled with $\left[\gamma^{32} \mathrm{P}\right] \mathrm{ATP}$ and T4 polynucleotide kinase.

The Northern blot was washed in a solution of $0.2 \times \mathrm{SSC} /$ $0.5 \%$ SDS at $68^{\circ} \mathrm{C}$ for $30 \mathrm{~min}$ and prehybridized in a solution of $0.5 \mathrm{M}$ sodium phosphate, $\mathrm{pH} 7.5,7 \%$ SDS, $1 \% \mathrm{BSA}, 1 \mathrm{mM}$ EDTA, pH 8, $50 \mu \mathrm{g} / \mathrm{mL}$ denatured salmon sperm DNA, and 10 $\mu \mathrm{g} / \mathrm{mL}$ polyriboadenylic acid at $68^{\circ} \mathrm{C}$ for $1 \mathrm{~h}$. Six $\times 10^{6} \mathrm{cpm}$ of rat transferase probe were added and the blot hybridized at $68^{\circ} \mathrm{C}$ for $24 \mathrm{~h}$. The blot was washed four times in $0.5 \times \mathrm{SSC} / 0.1 \% \mathrm{SDS}$ at $68^{\circ} \mathrm{C}$ for $15 \mathrm{~min}$. Autoradiography was performed with Kodak XAR-2 film at $-70^{\circ} \mathrm{C}$. Densitometry scans were obtained using a LKB Ultroscan XL enhanced laser densitometer and analyzed using LKB Gelscan XL software (LKB Instruments Inc., Gaithersburg, MD).

The transferase probe was stripped from the Northern blot by boiling in water. The blot was then prehybridized as above, and $10^{6} \mathrm{cpm}$ of end-labeled rat $18 \mathrm{~S}$ ribosomal RNA probe were added and allowed to hybridize for $16 \mathrm{~h}$. The blot was washed as above and autoradiographed at $-70^{\circ} \mathrm{C}$ for $4 \mathrm{~h}$ followed by densitometry scanning.

Data is presented as the average \pm SEM for $n=$ five to 11 animals. The $t$ test for paired data was used to determine levels of significance where $p<0.05$ is considered significant.

\section{RESULTS}

Regional activity of galactose-1-phosphate uridyltransferase. The $\mathrm{sp}$ act of galactose-1-phosphate uridyltransferase in six brain regions is shown in Figure 1. The highest $\mathrm{sp}$ act is found in the cerebellum with a mean \pm SEM of $9.05 \pm 0.18 \mathrm{nmol} / \mathrm{min} / \mathrm{mg}$ protein $(n=10)$, whereas the cortex, striatum, and hippocampus had lower levels of $4.96 \pm 0.18,4.25 \pm 0.25$, and $4.69 \pm 0.32$, respectively. These differ significantly from the cerebellum $(p<$ $0.001)$. The sp act of midbrain of $8.19 \pm 0.66(n=11)$ did not differ significantly from cerebellum or brain stem, $7.16 \pm 0.50$ $(n=11)$. The latter value, although only $21 \%$ lower, differed from the cerebellum with a $p<0.05$.

$m R N A$ expression of galactose-1-phosphate uridyltransferase. Figure 2 shows the autoradiograms of the Northern blots from cortex and cerebellum from three animals. Three bands are visible in each of the uridyltransferase lanes. The lower band, which is the major species, corresponds to the 1.4-kb mRNA expected for rat uridyltransferase (unpublished data) and is similar in size to the human mRNA (21). In addition to the major mRNA species, two minor bands, approximately 1.6 and $2 \mathrm{~kb}$ in size, are present in all three animals. The identity of these

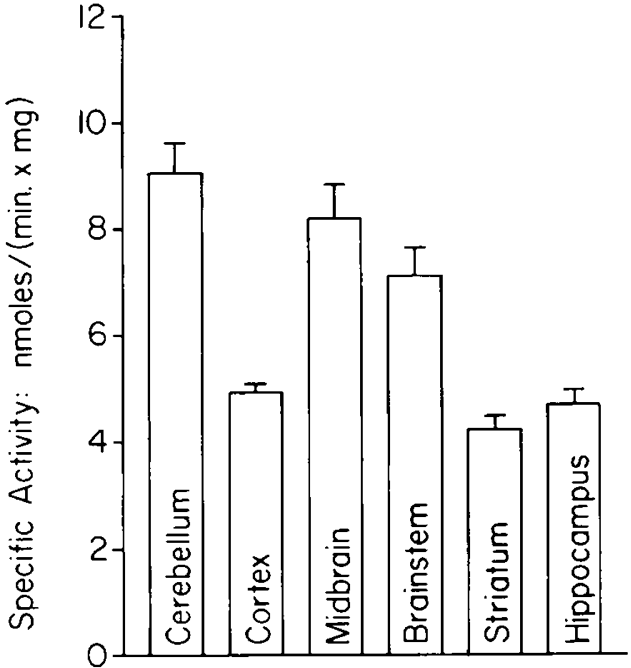

Fig. 1. Regional distribution of galactose-1-phosphate uridyltransferase. $\mathrm{Sp}$ act is expressed as nmol of product formed per min per $\mathrm{mg}$ soluble protein. Values for cortex are from gray matter-enriched preparations. Data represent averages with the SEM shown by error bars for $n$ $=$ five to 11 animals.

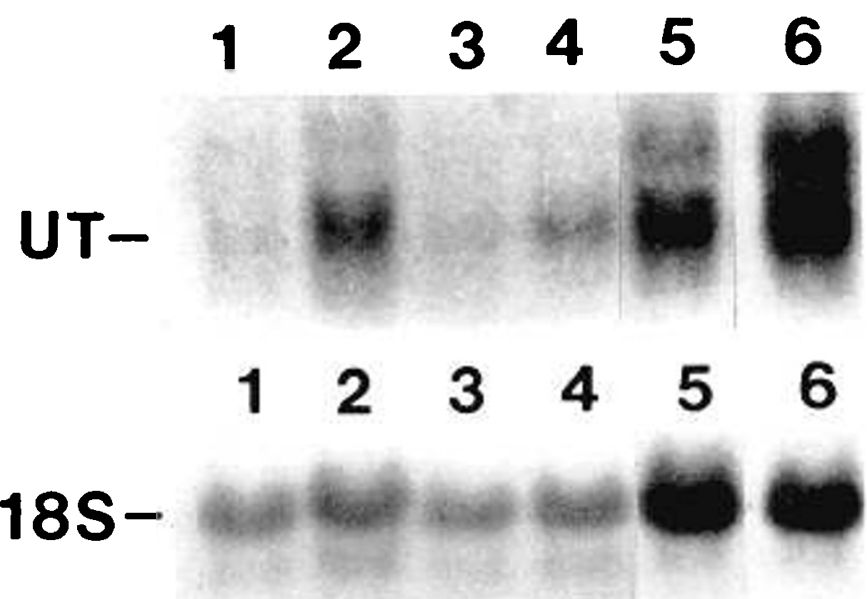

Fig. 2. Hybridization of ${ }^{32} \mathrm{P}$-labeled 786-bp rat transferase $\mathrm{cDNA}$ and rat $18 \mathrm{~S}$ ribosomal oligonucleotide to total RNA from rat brain cortex and cerebellum. Autoradiography was performed with Kodak XAR-2 for $4 \mathrm{~d}$ (lanes 1-4) or $5 \mathrm{~d}$ (lanes 5 and 6). Galactose-1-phosphate uridyltransferase mRNA (UT) and rat $18 \mathrm{~S}$ ribosomal RNA (I8S) from the cortex and cerebellum of a single animal are presented in adjacent lanes; lanes $I$ and 2 correspond to the cortex and cerebellum, respectively, from animal number 1 ; lanes 3 and 4 represent these regions from a second animal; lanes 5 and 6 those from the third.

bands is unknown, but they may represent either transferase premRNA or mRNA for an enzyme(s) with significant homology to transferase. The presence and intensity of these bands is variable between different tissues (unpublished data).

Figure 3 is a graphic representation of the densitometry analysis of the data in Figure 2. The ordinate units represent Gaussian areas under the densitometry curves, which have been standardized to rat $18 \mathrm{~S}$ ribosomal RNA. The average ratio of areas of cerebellum to cortex is 2.16 for three animals. The ratio of uridyltransferase $\mathrm{sp}$ act of the two regions as shown in Figure 1 is 1.82 .

Kinetics of transferase in cerebellum and cortex. Because the cerebellum and cortex are areas of the brain known to be involved in the neurologic disturbances occurring in galactose$\mathrm{mia}$, these regions were examined in further detail to determine the kinetic basis of the site-specific differences observed in the sp act of the enzyme. These data are represented as double recip- 


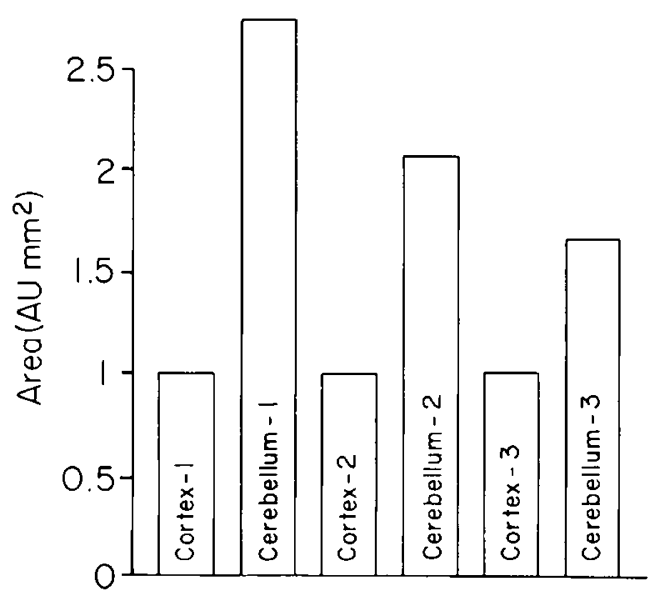

Fig. 3. Histogram of densitometry obtained from Northern blots shown in Figure 2. Areas in absorption units under densitometry curves were standardized to rat $18 \mathrm{~S}$ ribosomal RNA. Cortex areas were brought to unity and cerebellar values adjusted proportionately.

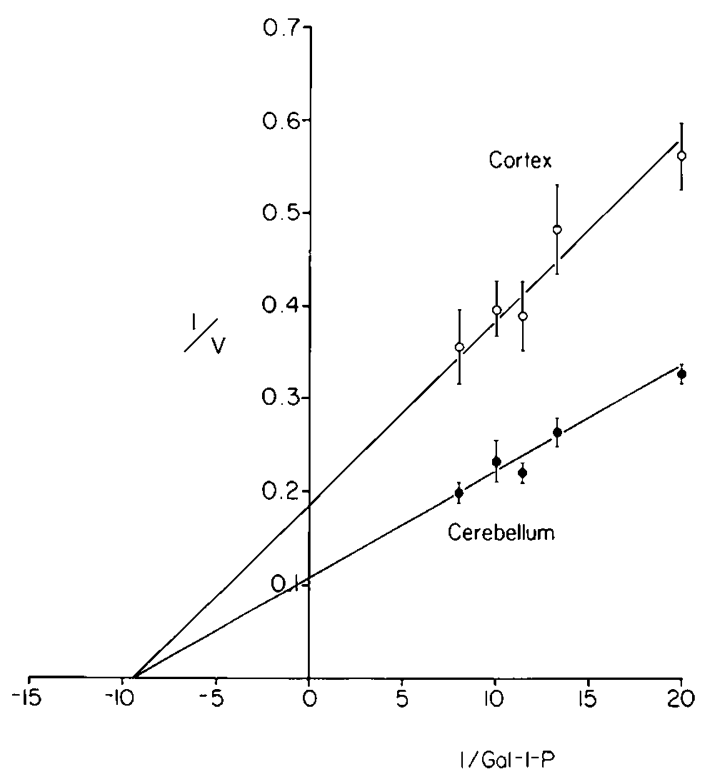

Fig. 4. Concentration dependence of galactose-1-phosphate uridyltransferase with respect to galactose-1-phosphate ( $G$ al-1-P) in homogenates of cerebellum and cortex from adult rat brains. Linear regression analysis of initial velocities obtained with $0.25 \mathrm{mM}$ UDPglucose was used to compute the lines shown. Sp act $(v)$ are expressed as nmol of product formed per min per mg soluble protein. Data represent averages with the SEM shown by error bars for three preparations, each assayed in duplicate, where tissue was combined from two to three animals to obtain a sufficient sample size.

rocal plots shown in Figures 4 and 5, where linear regression analysis of the data was used to compute the apparent MichaelisMenten constants given in Table 1. No differences were found for the apparent $\mathrm{Km}$; however, the apparent $\mathrm{V}_{\max }$ with respect to both substrates was significantly higher for the cerebellum.

Enzyme modulation. A previous report examining the effects of modulators on the enzyme activity in homogenates of whole rat brain showed that uridine and UTP are inhibitors of enzyme activity at concentrations as low as $0.05 \mathrm{mM}(22)$. We, therefore, examined the effects of these inhibitors on activity in each region of the brain to determine if the site-specific differences observed in enzyme activity relate to the degree of inhibition by uridine and UTP. Inhibition by uridine varied from 37 to $46 \%$. Regions with high transferase were not significantly inhibited more than those with low enzyme activity (Fig. 6). The percentage of inhibition by UTP was lower than that observed for uridine,

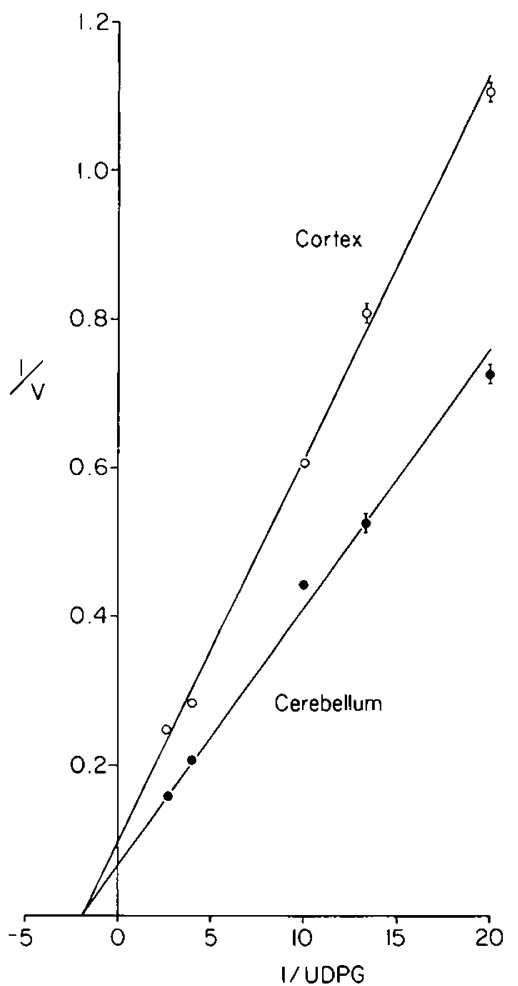

Fig. 5. Concentration dependence with respect to UDPglucose $(U D P G)$ of the enzyme from cerebellum and cortex of adult rat brains. The concentration of galactose-1-phosphate is $0.35 \mathrm{mM}$. Other conditions and expression of enzyme activity are given in Figure 4.

Table 1. Kinetic parameters of galactose-1-phosphate uridyltransferase of rat brain cerebellum and cortex*

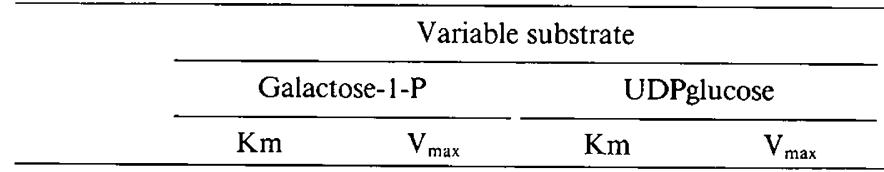

Cerebellum $0.103 \pm 0.0069 .29 \pm 0.73 \dagger 0.506 \pm 0.05114 .60 \pm 0.69 \dagger$ $\begin{array}{lllll}\text { Cortex } & 0.104 \pm 0.004 & 5.28 \pm 0.40 & 0.513 \pm 0.052 & 10.02 \pm 0.71\end{array}$

${ }^{*} \mathrm{Km}$ is in $\mathrm{mmol} / \mathrm{L}$. $\mathrm{V}_{\max }$ is in $\mathrm{nmol}$ formed $/ \mathrm{min} / \mathrm{mg}$. Fixed concentrations of galactose-1-P and UDP glucose are 0.35 and $0.25 \mathrm{mmol} / \mathrm{L}$, respectively. Data were obtained in three separate experiments where tissue of two to three animals was combined to obtain sufficient sample size. All determinations were made in duplicate.

$\dagger p<0.01$.

varying between 30 and $35 \%$. For each region, inhibition by uridine was significantly greater $(p<0.01-0.05)$ than for an equal concentration of UTP.

\section{DISCUSSION}

The analysis of regional distribution of galactose-1-phosphate uridyltransferase activity in rat brain demonstrates that the cerebellum, midbrain, and brain stem have the highest levels. The data indicate that the higher enzyme sp act of the cerebellum compared with cortex is paralleled by a comparable difference in steady state mRNA level. These results suggest a genetic control mechanism is operative to maintain higher amounts of enzyme in the cerebellum. The kinetic analysis showing a greater $\mathrm{V}_{\max }$ for cerebellum than cortex without alteration in the $\mathrm{Km}$ is consistent with there being more enzyme protein in cerebellum.

Because the brain is a multifunctional organ, the finding of regional specificity for enzyme activity is not unusual. Litteria and Popoff (23) have reported that rat brain uridine kinase is highest in cerebellum. The activity of $11-\beta$-hydroxysteroid dehydrogenase activity in cerebellum is also high and, like uridyl- 


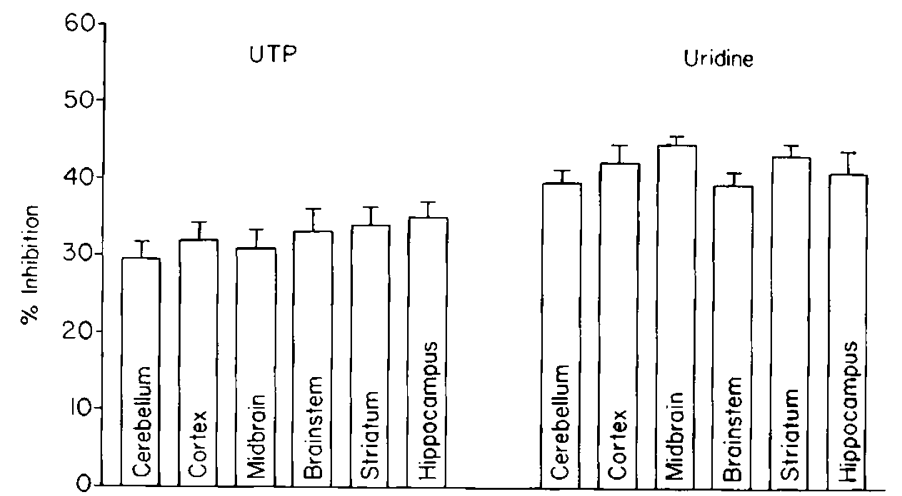

Fig. 6. Effect of UTP and uridine on the $\mathrm{sp}$ act of galactose-1phosphate uridyltransferase in rat brain homogenates. The concentration of inhibitor used was $0.4 \mathrm{mmol} / \mathrm{L}$. Data are expressed as the percentage of inhibition of values obtained in the absence of inhibitor where each sample served as its own control. Error bars represent the SEM for $n=$ five to 11 animals.

transferase, mRNA expression correlates with the enzyme activity (24). Because we examined whole cerebellum or brain regions grossly, we have no knowledge of the enzyme distribution in various cellular elements in these areas. Dagani et al. (25), however, have reported data on a variety of enzyme activities in subcellular fractions of rat brain cortex and cerebellum. Citrate synthase activity was higher in cerebellar mitochondria, and cytochrome oxidase was higher in a cerebellar synaptosome fraction. Lowry et al. (26) have shown human cerebellar pyruvate kinase and citrate synthase activity to be higher than that in cerebral cortex.

Our knowledge of galactose metabolism in these regions is insufficient to postulate why some regions of the brain might require higher levels of this enzyme. One possibility is the need to maintain a sufficient pool size of UDPgalactose, the product of the transferase reaction with galactose-1-phosphate anc UDPglucose, which is required to synthesize complex glycoproteins and galactolipids. Both a deficiency of UDPgalactose (27) and evidence for a galactosylation defect in galactosemic cells $(28,29)$ have been suggested as a basis of long-term complications of galactosemia.

Because uridine administration has been advocated as a preventive measure for long-term complications of galactosemia (30), we have investigated the effects of uridine and its metabolic product UTP on galactose-1-phosphate uridyltransferase activity in rat liver (31), ovary, and whole rat brain (22). Both compounds inhibit the enzyme at relatively low concentrations where the effects are additive. The present findings demonstrate that uridine and UTP inhibit transferase activity to the same extent in various brain regions without regard to the differences in enzyme activity. Because Litteria and Popoff (23) have reported that rat brain uridine kinase is highest in cerebellum, the administration of uridine could lead to conversion to UTP, as we have found in the liver (31), with the possibility of a greater abundance in cerebellum than elsewhere. Such a phenomenon would suggest a possible detrimental aspect to uridine administration in galactosemic patients, in whom residual transferase activity could be inhibited (21).

Although mental retardation has been a prominent finding in classic galactosemic patients, in whom this enzyme is deficient $(1-3)$, an additional feature has been a neurologic syndrome of cerebellar dysfunction (7-10). Indeed, in several reports of computed tomography or magnetic resonance imaging examinations of such patients, cerebellar alterations have been described $(9$, 10). In addition, in a limited number of autopsy examinations of galactosemic brains, brain stem and cerebellar atrophy have been found with disruption of the cerebellar Purkinje cell layer (9-11). Such findings taken in conjunction with the regional distribution of the involved enzyme in rat brain lead us to speculate that the loss of the high enzyme activity in the cerebellum may make that region particularly vulnerable to the resulting abnormality of galactose metabolism.

Acknowledgment. The authors thank Isabella A. Fisher for typing the manuscript.

\section{REFERENCES}

1. Segal S 1989 Disorders of galactose metabolism. In: Scriver $\mathrm{CH}$, Beaudet AL, Sly WS, Valle D (eds) The Metabolic Basis of Inherited Diseases, Vol II, 6th ed. McGraw-Hill, New York, pp 453-480

2. Fishler K, Koch R, Donnell GN, Wenz E 1980 Development aspects of galactosemia from infancy to childhood. Clin Pediatr 19:38-44

3. Waggoner DD, Buist NRM, Donnell GN 1990 Long-term prognosis in galactosaemia: results of a survey of 350 cases. J Inherited Metab Dis 13:802-818

4. Waisbren SE, Norman TR, Schnell RR, Levy HL 1983 Speech and language deficits in early-treated children with galactosemia. J Pediatr 102:75-77

5. Nelson CD, Waggoner DD, Donnell GN, Tuerch JM, Buist NRM 1990 Verbal dyspraxia in treated galactosemia. Pediatrics 88:346-350

6. Huttenlocher PR, Hillman RE, Hsia YE 1970 Pseudotumor cerebri in galactosemia. J Pediatr 76:902-905

7. Jan JE, Wilson RA 1973 Unusual late neurologic sequelae in galactosaemia. Dev Med Child Neurol 15:72-74

8. Lo W, Packman S, Nash S, Schmidt K, Ireland S, Diamond I, Ng W, Donnell GN 1984 Curious neurologic sequelae in galactosemia. Pediatrics 73:309312

9. Bohles H, Wenzel D, Shin YS 1986 Progressive cerebellar and extrapyramidal motor disturbances in galactosaemic twins. Eur J Pediatr 145:413-417

10. Friedman JH, Levy HL, Boustany R 1989 Late onset of distinct neurological syndromes in galactosemic siblings. Neurology 39:741-742

11. Crome L 1962 A case of galactosaemia with the pathological and neuropathological findings. Arch Dis Child 37:415-429

12. Haberland C, Perou M, Brunngraber EG 1971 The neuropathology of galactosemia: A histopathological and biochemical study. J Neuropathol Exp Neurol 30:431-447

13. Suzuki H, Gilbert EF, Anido V, Jones B, Klingberg WG 1966 Galactosemia: Report of two fatal cases. Arch Pathol 82:602-609

14. Bertoli D, Segal S 1966 Developmental aspects and some characteristics of mammalian galactose- 1 -phosphate uridyltransferase. J Biol Chem 241:40234029

15. Rogers S, Segal S 1981 Changing activities of galactose-metabolizing enzymes during perfusion of suckling rat liver. Am J Physiol 240:E333-E339

16. Rogers S, Bovee BW, Saunders S, Segal S 1989 Activity of hepatic galactosemetabolizing enzymes in the pregnant rat and fetus. Pediatr Res 25:161-166

17. Rogers SR, Bovee BW, Saunders SL, Segal S 1989 Galactose as a regulatory factor of its own metabolism by rat liver. Metabolism 38:810-815

18. Lineweaver H, Burk DJ 1934 The determination of enzyme dissociation constants. J Am Chem Soc 56:658-666

19. Chomczynski P, Sacchi N 1987 Single-step method of RNA isolation by acid guanidinium thiocyanate-phenol-chloroform extraction. Anal Biochem 162:156-159

20. Sambrook J, Fritsch EF, Maniatis T 1989 Molecular Cloning: a Laboratory Manual, 2nd ed. Cold Spring Harbor Laboratory Press, Cold Spring Harbor, NY

21. Rogers S, Segal S 1991 Modulation of rat tissue galactose-1-phosphate uridyltransferase by uridine and uridine triphosphate Pediatr Res 30:222-226

22. Rogers S, Segal S 1971 Nucleotide inhibition of mammalian liver galactose-1phosphate uridyltransferase. Biochim Biophys Acta 250:351-360

23. Litteria M, Popoff CG 1985 Postnatal ontogeny of uridine kinase in the cerebellum, hypothalmus, and cerebral cortex of the rat. Neurochem Res 10:63-75

24. Moisan MP, Seckl JR, Edwards CRW $199011 \beta$-hydroxysteroid dehydrogenase bioactivity and messenger RNA expression in rat forebrain: localization in hypothalmus, hippocampus, and cortex. Endocrinology 127:1450-1455

25. Dagani F, Marzatico F, Taglietti M, Zanada F, Benzi G 1984 Influence of intermittent hypoxia and pyrimidinic nucleosides on cerebral enzymatic activities related to energy transduction. Neurochem Res 9:1085-1099

26. Lowry OH, Berger SJ, Carter JG, Chi M M-Y, Manchester JK, Knor J, Pusateri ME 1983 Diversity of metabolic patterns in human brain tumors: enzymes of energy metabolism and related metabolites and cofactors. J Neurochem 41:994-1010

27. Ng WG, Xu YK, Kaufman FR, Donnell GN 1989 Deficit of uridine diphosphate galactose in galactosaemia. J Inherited Metab Dis 12:257-266

28. Dobbie JA, Holton JB, Clamp JR 1990 Defective galactosylation of proteins in cultured skin fibroblasts from galactosemic patients. Ann Clin Biochem 27:274-275

29. Ornstein KS, McGuire EJ, Berry GT, Roth S, Segal S 1992 Abnormal galactosylation of complex carbohydrates in cultured fibroblasts from patients with galactose-1-phosphate uridyltransferase deficiency. Pediatr Res 31:508511

30. Kaufman FR, Ng WN, Xu YK, Guidici T, Kaleita TA, Donnell GN 1989 Normalization of uridine diphosphate galactose (UDPGal) levels with oral uridine in patients (PTS) with classical galactosemia (G) with oral uridine. Pediatr Res 25:834(abstr)

31. Rogers S, Bovee BW, Segal S 1989 Effect of uridine on hepatic galactose-1 phosphate uridyltransferase. Enzyme 42:53-60 